\title{
EVALUATION OF ANATOMOPATHOLOGICAL, SEROLOGICAL, IMMUNOLOGICAL RESPONSES AND PROTECTION IN BROILERS VACCINATED WITH LIVE INFECTIOUS BURSAL DISEASE VACCINES
}

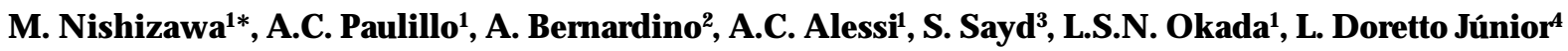

IUniversidade Estadual Paulista, Facul dade de Ciências Agrárias e Veterinárias, Departamento dePatologia Veterinária, Via de A cesso Prof. Paulo Donato Castellane, s/ no, CEP 14884-900, Jaboticabal, SP, Brasil.

\begin{abstract}
The study was divided into three experiments. In the first one, broilers were distributed into six groups and vaccinated against infectious bursal disease at 14 days of age: T1-not vaccinated, T2-Lukert ${ }^{1}$ (intermediate), T3-Lukert ${ }^{2}$ (intermediate plus), T4-228E, T5-V877 and T6-Winterfield 2512 ("hot" strains). Bursas of Fabricius (BF) were collected at 17, 21, 28 and 35 days to measure BF relative weight (BFRW), diameter, histological examination and image processing analysis (IPA ). A tone, 14, 21, 28and 35 days of age, samples of blood taken fromeight birdsfromeach group for serology analysis by ELISA test. Hot strains vaccines induced reduction of BFRW and BF diameter, higher histological scorelesion degree, morelymphocytedepletion on theBF follicles and higher IBD antibody titer. In thesecond experiment, 16birdsfromgroupsT1 to T6wereisolated and challenged with a very virulent strain of IBDV (vvIBDV) at 25 days of age. Only groups T4, T5 and T6 were totally protected against vVIBDV challenge. In the third experiment, the immunosuppressivepotential of each vaccinewas determined by examining theability of IBDVvaccinated birds to respond to $\mathrm{N}$ ewcastle disease (ND) vaccination and challenge. None of the vaccines was found to be immunodepressive.
\end{abstract}

KEY WORDS: I nfectiousBursal Disease, very virulentinfectiousbursal diseasevirus, livevaccines, bursa of Fabricius, broilers, immunosuppression.

\section{RESUMO}

AVALIAÇÃO DAS RESPOSTAS ANATOMOPATOLÓGICA, SOROLÓGICA, IMUNONOLÓGICA E PROTETORA EM FRANGOS DE CORTE VACINADOS COM VACINAS VIVASCONTRA A DOEN ÇA INFECCIOSA DA BURSA. O estud ofoi dividido em três experimentos. N o primeiro, frangosforam distribuídosemseisgrupos evacinadoscontraaDoençal nfecciosa da Bursa (IBD) aos 14 dias de idade: T1-não vacinados, T2-Lukert ${ }^{1}$ (intermediária), T3-Lukert ${ }^{2}$ (intermediária plus), T4-228E, T5-V877 eT6-Winterfiel d 2512 (cepa forte). As bursas de Fabrícius (BF) foram col hidas aos 17, 21, 28 e 35 dias para mensurar o seus pesos rel ativos da BF (BFRW), diâmetros, exames histológicos e processamento de imagem imagens(IPA ). A o primei ro, 14, 21, 28e35dias deidade, foram colhidasamostras desanguedeoito aves decadagrupo paraa realização desorologiaatravésdo métodoELISA indireto. Asvacinas cepaforteinduziram redução do BFRW peso e do diâmetro da BF, maior grau de lesão histológica e depleção linfocitária e títul os mais elevados de anticorpos. No segundo experimento, 16 aves dos grupos T1 ao T6 foram isoladas e desafiadas com o vírus muito virulento da IBD (vvIBDV) aos 25 dias deidade. Somenteos grupos T4, T5 e T6 foram completamente protegidos do desafi o com vVIBDV. N o terceiro experimento, o potencial imunossupressor de cada vacina foi determinado através da capacidade das aves vacinadas responderem à vacinação contra a Doença de Newcastle (ND) e posterior desafio. Nenhuma vacina apresentou-se imunossupressora.

PALAVRAS-CHAVE: DoençaInfecciosadaBursa, vírusmuito virulento, vacinasvivas atenuadas, bursa de Fabrícius, frangos de corte, imunossupressão.

\footnotetext{
${ }^{2}$ Fort Dodge Saúde Animal, Campinas, SP, Brasil.

3Idexx Laboratórios, São Paulo, SP, Brasil.

${ }^{4}$ LARA, Campinas, SP, Brasil.

*Aluna do Programa de Pós-Graduação em M edicina Veterinária da FCA V-UNESP.
} 


\section{INTRODUCTION}

Infectiousbursal diseasevirus(IBDV) isamember of Birnaviridae family, non-enveloped with icsosahedral symmetry and a diameter varying from 55 to $65 \mathrm{~nm}$. Thevirus has genomes consisting of two segments of double-stranded RNA (LOBARDo et al., 1999; SCHRÖDER et al., 2000).

The clinical disease of IBD, first described by Cosgrovein 1962, affectschicks between 3and 6weeks of age, during over 8 to 10 days. It is characterized by ruffled feathers, whitish or watery diarrhea, anorexia, depression, trembling, severe prostration and finally death. The target organ of the virus is the lymphoid tissue, specially the bursa of Fabricius that has a gelatinous yellowish transudate covering the serosal surface. Longitudinal striations on thesurfacebecome prominent, and thenormal whitecolor turnsto cream. The transudate disappears as the bursa returns to its normal size and becomes gray during the following period of atrophy. The infected bursa often shows necrotic foci and at times ecchymotic hemorrhages on the mucosal surface. Occasionally, extensive hemorrhage throughout the entire bursa has been observed (LuKeRT ; SAIF, 1997; Sellers et al., 1999).

Susceptible chicks younger than 3 weeks do not exhibit clinical signs, but havesubclinical infections that are economically important as a result of severe immunosuppression of thechicken (LUKERT;SAIF, 1997).

In the late 1980', IBD caused low mortality, with economical loss due to the immunosuppression (SKInNER, 2000). At that time mild vaccines were introduced, followed by inactivated and intermediate vaccines. Since then, until the beginning of 1990 decade, samples of IBDV isolated in those countries had moderatepathogenicity (SAUKAS, 1978; ITO, 1981; ITO, 1990).

Intheearly 1990, Brazil wasfollowingthestrategy of IBD prevention and control used in theUSA. Mild and intermediatevaccines wereproduced using field IBDV with mild pathogenicity, attenuated by adaptation after several blind passages in cell culture or embryonated eggs (ITO, 2002).

The situation changed rapidly, however, in the late 1980' with theemergence of a pathotypicvariant, firstobserved in theBenelux countries (VAN DEN BERG; Meulemans, 1991). This variant termed very virulent, spread rapidly throughout mainland Europe (ETeradossl et al., 1992).

SinceJuly 1997, the vvIBDV, genomicgroup 11 (G 11-Simbios) had been observed in somebroiler farms located in Campinas, São Paulo State (Dı FABıo etal., 1999). Bursas from 27-day-old diseased broilers were sent for virus characterization to the AFSSAPloufragan laboratory, France. In an antigen-capture ELISA base $d$ on seven neutralizing monoclonal antibodies, homogenates derived from thesubmitted bursa were shown to contain IBDV particles antigenically similar to the vvlBDVs collected in Europe since 1981 (ETERADossi et al., 1997). Clinical and virological data suggested that the very virulent form of IBD was present in Brazil. One of the virus envolvedinvolved shared antigenic, genetic and pathogenicpropertieswith European vvIBDV strains (DI FABIo et al., 1999).

Thecontrol of vvIBDV in Europewas donein part by the use of live vaccines, which primarily did not differed not primarily in their antigenicity but in their pathogenicity. Thus, instead of mild vaccines, intermediate vaccines were used routinely, with hot vaccines being used use don heavily contaminated sites. The rationale behind this successful approach wasthat thehotter vaccineswould beabletotakein the face of higher levels of maternal antibodies, allowing chicksto bevaccinated earlier, beforeinfection with the vvIBDV. Such an approach though depends on strict hygiene and management to reduce levels of contamination with vVIBDV. Moreover, vaccination protocols have to be strictly adhered to so that vaccinationiseffectivewithoutcausingadverseeffects on growth or immunesystem function (SKINNER, 2000).

The immunization of breeder flocks is very important to confer parental immunity to their progeny. Antibody transmitted via the yolk sac can protect chicks against early infections with IBDV, withresultant protection againstimmunosuppressive effect of the virus (LUKERT; SAIF, 1997). The half-life of maternal antibodies to IBDV is between 3 and 5 days (SkEELEs etal., 1979). Such maternal antibodiesprotect the chick from early immunosuppressive infections, protecting them for 1 to 3 weeks, but by boosting the immunity inbreeder flockswithoil-adjuvantvaccines, passive immunity may be extended to 4 or 5 weeks (BAXENDALE; LUTTICKEN, 1981).

Thepresent study was carried out to evaluate the anatomopathological, serological, immunological responses and protection in broilers vaccinated with five commercial live IBD vaccines and challenged with vvIBDV strain.

\section{MATERIAL AND METHODS}

\section{Experimental birds and management}

A total number of 560 day-old male Ross broiler chickens were distributed into seven treatments of 80 birdseach. Thegroup was divided into four repetitions with 20 broilers each, housed in boxes over litter, keeping distance between the other groups. They werewatered and fed ad libitum abroiler corn-soyben starter diet ( $21.5 \%$ protein and $3.073 \mathrm{kcal} / \mathrm{kg} \mathrm{ME}$ ). 


\section{Experimental Design}

Thestudy was divided into three experiments. In the first, therewere six groups of 80 birds each. Each group represented four replicates of 20 birds each. The firstgroup (T1) wasunvaccinated (IBD control group). The Group T2 group received Lukert intermediate strain, T3 Lukert intermediate plus strain, T4 228E strain, T5V877strain and T6Winterfield 2512strain. At 17, 21, 28 and 35 days of age, eight randomly selected broilers of each group werenecropsied. They were individually weighted and had their BF measured, weighted and taken for histological and IPA observation. Atone, 14, 21, 28and 35days of age, eight birds from each group had their blood samples collected for serology analysis by ELISA test.

Inthesecond experiment, at 25 days of age, 16 birds from each group (T1 to T6) werekept in isolators and werechallenged. Each bird received, oral via, $0.5 \mathrm{~mL}$ of VvIBDV suspension $\left(10^{4.0} \mathrm{DIE}_{50} 0.1 \mathrm{~mL}\right)$ by ,oral via. The protection against vvIBDV challenge was measured by the mortality, clinical signs and macroscopiclesions observation observed during 10 days of challenge. Those birds that did not showed mortality or clinical signs of the disease were killed and necropsied at the end of the challenge period.

In thelast experiment, thesamesix vaccine groups consisting of four replicates per group, as in the first experiment were used. In addition, a seventh group consisting of four replicates of 20 birds each, werewas notIBDV nor ND vaccinated. BirdsfromT1to T6groups werevaccinated at21 days of ageagainstND. At35days of age, 16birdsfromeach group (T1toT7) werekeptinto isolatorsand challenged withviscerotropicNDV.Serum Serawerecollected at21, 28and 35daysof ageto perform hemagglutination inhibition test $(\mathrm{HI})$ to check antibody concentration. They weremaintained under observation for 10 days post challenge. The protection against ND challengewasmeasured by themortality, clinical signs and macroscopic lesions observation observed during the challenge period. At 45 days of age, all remainigremaining challenged birds were killed and necropsied (Table1).

\section{IBD vaccines and vaccination}

Thefollowing fivelive commercial vaccines were given by intra-conjunctiva instillation at 14 days of age: T2-Lukert ${ }^{1}$ (intermediate strain), T3-Lukert ${ }^{2}$ (intermediate plus strain), T4-228E, T5-V877 and T6Winterfield 2512 ("hot" strains). Groups T1 and T7 were not vaccinated against IBD.

\section{Bursa of Fabricius relative weight (BFRW)}

At $17,21,28$ and 35 days of age, eight birds of each group were individually weighted, sacrificed and necropsied. Thebursas weresampled, weighted and had their diameter measured. The ratio between the bursa of Fabriciusand body weight was calculated by dividing the bursa weight for the body weight multiplied by 1000 .

\section{D iameter of the Bursa of Fabricius}

A total of 32 bursas of Fabricius per group were submitted to diameter qualitative measurement and given scores from 1 to 8 , based on the following parameters: score 1 (diameter up to $3.17 \mathrm{~mm}$ ); score 2 (from 3.18 to $6.35 \mathrm{~mm}$ ); score 3 (from 6.36 to $9.52 \mathrm{~mm}$ ); score4(from 9.53to $12.7 \mathrm{~mm}$ ); score5(from 12.8to 15.87 $\mathrm{mm}$ ); score 6 (from 15.88 to $19.05 \mathrm{~mm}$ ); score 7 (from 19.06to $22.22 \mathrm{~mm}$ ); and score 8 (from 22.23 to $25.4 \mathrm{~mm}$ ). For this, it was used a ruler that contains holes with different diameters to each score (Bursometer suppiedsupplied by FortDodgeA nimal Health, Brazil).

Table 1 - Experimental groups.

\begin{tabular}{lclccc}
\hline Groups & $\begin{array}{c}\text { Number } \\
\text { of birds }\end{array}$ & $\begin{array}{c}\text { IBD vaccination } \\
\text { (14 days) }\end{array}$ & $\begin{array}{c}\text { ND vaccination } \\
\text { (21 days) }\end{array}$ & $\begin{array}{c}\text { IBD challenge } \\
\text { (25 days) }\end{array}$ & $\begin{array}{c}\text { ND challenge } \\
\text { (35 days) }\end{array}$ \\
\hline T1 & 80 & - & LaSota & vvlBDV & NDV \\
T2 & 80 & Lukert $^{1}$ & LaSota & VVIBDV & NDV \\
T3 & 80 & Lukert $^{2}$ & LaSota & vvIBDV & NDV \\
T4 & 80 & 228E & LaSota & vVIBDV & NDV \\
T5 & 80 & V87 & LaSota & VvIBDV & NDV \\
T6 & 80 & Winterfield 2512 & LaSota & vvIBDV & NDV \\
T7 & 80 & - & - & & NDV \\
\hline
\end{tabular}

\footnotetext{
${ }^{1}=$ intermediate strain

${ }^{2}=$ intermediate plus strain

vVIBDV =very virulent infectious bursal disease virus

NDV $=$ Newcastle Disease Virus
} 


\section{Histological observation}

At 17, 21, 28and 35days of age, thebursas of four birds of each group had theirwere bursa fixed in $10 \%$ phosphate-buffered formalin. They were included in paraffin and fine cuts of $5 \mu$ were prepared, mounted between glass slides and coverslipsand stained with hematoxilin and eosin. All cuts were examined in a light microscope and scored according to severity of damageon a scaleof 0 (none), 1 (minimal), 2 (mild), 3 (moderate), 4 (marked) and 5 (severe), by the following criteria: hemorrhage, lymphoid necrosis, Iymphoid depletion, heterophilicinflammation, fibrosis, cyst formation and reticuloendothelial hiperplasia. A mean score for each lesion was then determined from the collected bursas.

\section{Image processing analysis}

Thehistological sampleswereused to measurethe percentage of lymphocytes present in the bursa. A microscope connected to a computer reads the percentageof lymphocytes containing in thebursa by a computer program called E-bursa, developed by Fort Dodge Animal Health.

\section{Serological analysis}

Eight serum samples per group were collected aseptically at one, 14, 17, 21, 28 and 35 days of age. Samples wereheated at $56^{\circ} \mathrm{C}$ for 30 minutesand kept frozen at $-20^{\circ} \mathrm{C}$ until used. They were submitted to ELISA commercial test (IBD-Idexx $®)$.

\section{IBD challenge inoculum}

A strain of IBDV was isolated from bursa of Fabricius of natural infected birds. The strain was characterized as a very virulent strain (VvIBDV) and identified by RT-PCR asgenomic pattern 11 (G11), as described by IKUTA et al. (2001).

\section{IBD challenge}

Sixteen birds from groups T1 to T6 groups were challenged by oral via at 25 days of age. They were given a suspension of $0.5 \mathrm{~mL}$ per broiler of vVIBDV. Fifty percent of thebirds of each group werechosen at random to besacrificed four days post challenge and the rest of them were sacrificed ten days after challenge. All of these broilers were observed to identify clinical signs suggesting IBD and were necropsied to observemacroscopiclesions, such as edema, hemorrhage and gelatin-like exsudate on the BF.

\section{N ew castle disease (N D ) vaccination}

A LaSotastrain of N ew castlediseasevirus(NDV) wasused in thistrial. BirdsfromT1 to T6groupswere vaccinated at 21 days of age, each with onedrop $(0.03$ $\mathrm{mL}$ ) of LaSota vaccine by intra-conjuntictiva instillation. Birds from T7 group (Table 1) were not vaccinated neither against IBD nor ND, constituting the control group of ND.

Table 2 - Mean bursa weight in grams divided by body weight in grams $\times 1000$ (BFRW) of the experimental groups at different ages.

\begin{tabular}{llllll}
\hline & & \multicolumn{4}{c}{$\begin{array}{c}\text { Mean bursa weight } \\
\text { body weight (BFRW) }\end{array}$} \\
\cline { 3 - 6 } .Groups & \multicolumn{4}{c}{ Vaccines } & \multicolumn{4}{c}{ Age (days) } \\
\cline { 3 - 6 } & & 17 & 21 & 28 & 35 \\
\hline T1** $^{*}$ & & $3.11^{a *}$ & $3.04^{\mathrm{a}}$ & $3.00^{\mathrm{a}}$ & $3.02^{\mathrm{a}}$ \\
T2 & Lukert $^{1}$ & $2.84^{\mathrm{a}}$ & $2.86^{\mathrm{a}}$ & $2.84^{\mathrm{ab}}$ & $2.54^{\mathrm{b}}$ \\
T3 & Lukert $^{2}$ & $2.98^{\mathrm{a}}$ & $3.45^{\mathrm{a}}$ & $2.72^{\mathrm{ab}}$ & $2.14^{\mathrm{b}}$ \\
T4 & 228E & $3.22^{\mathrm{a}}$ & $3.37^{\mathrm{a}}$ & $1.69^{\mathrm{bc}}$ & $0.95^{\mathrm{c}}$ \\
T5 & V877 & $2.77^{\mathrm{a}}$ & $2.41^{\mathrm{a}}$ & $1.06^{\mathrm{c}}$ & $0.85^{\mathrm{c}}$ \\
T6 & Winterfield 2512 & $3.33^{\mathrm{a}}$ & $2.53^{\mathrm{a}}$ & $1.36^{\mathrm{c}}$ & $0.92^{\mathrm{c}}$ \\
\hline
\end{tabular}

$1=$ intermediate strain

${ }^{2}=$ intermediate plus strain

*Means with different subscripts with the same column differ significantly $(p<0.05)$

**IBD control group: non vaccinated against IBD

\section{ND challenge}

At 35 days of age, 16 birds per group (T1 to T6 groups) werechallenged with viscerotropicN D virus strain. Thevirus has intra-cerebral pathogenicindex of 1.78 and embryonic death time of 48 hours, with a $50 \%$ embryo infecting dose titer of $8.15 \log _{10} 0.1 \mathrm{~mL}$. Distilled water was used as diluent for theinoculum that was instilled by oculo-nasal route, according to theU.S. Code of Federal Regulations (1993).

\section{Statistical analysis}

Data were submitted to statistical analysis by using GLM of SAS, and treatment means were compared at $5 \%$ probability level $(p<0.05)$.

\section{RESULTS}

Experiment 1: " $\mathrm{H}$ ot" strain vaccines ( $\mathrm{T} 4, \mathrm{~T} 5$ and T6) weremoreinvasiveand pathogenicthan theother groups, as evidenced by lower BFRW ratio, smaller 
diameter of theBF, higherlymphocytedepletion degree, lower lymphocyte percentage in the BF and higher antibody titers. As expected, thenon-IBD vaccinated group (T1) did not show any disorder in the BF and did not presented elevation in the IBD antibody titer.

\section{Bursa of Fabricius relative weight (BFRW)}

Theanalysis of Table2 revealed thatbirdsfrom T4, T5 and T6groups had significant reduction $(p<0.05)$ in BFRW ratio from 28 to 35 days of age. A little reduction could beobserved in T2and T3groupsat 35 days of age.

\section{Diameter of the bursa of Fabricius}

TheBursa of Fabricius from T4, T5and T6groups, representing the "hot" IBD strains, was smaller than the other groups from 28 to 35 days of age (Table 3 ).

Table3-M easurM Mesurement of the Bursa of Fabricius by the bursometer at 17, 21, 28 and 35 days of age in broiler chickens vaccinated at 14 days of age.

\begin{tabular}{llllll}
\hline & & \multicolumn{4}{c}{$\begin{array}{c}\text { Mean of } \\
\text { bursa diameter }\end{array}$} \\
\cline { 3 - 6 } Groups & Vaccine & \multicolumn{4}{c}{ Age (days) } \\
\cline { 3 - 6 } & & 17 & 21 & 28 & 35 \\
\hline T1** $^{*}$ & - & $4.63^{\mathrm{a} *}$ & $5.50^{\mathrm{a}}$ & $6.00^{\mathrm{a}}$ & $6.88^{\mathrm{a}}$ \\
T2 & Lukert $^{1}$ & $4.38^{\mathrm{a}}$ & $5.38^{\mathrm{a}}$ & $5.63^{\mathrm{ab}}$ & $6.00^{\mathrm{a}}$ \\
T3 & Lukert $^{2}$ & $4.50^{\mathrm{a}}$ & $5.38^{\mathrm{a}}$ & $5.63^{\mathrm{ab}}$ & $5.88^{\mathrm{a}}$ \\
T4 & 228E & $4.63^{\mathrm{a}}$ & $5.25^{\mathrm{a}}$ & $4.63^{\mathrm{bc}}$ & $4.50^{\mathrm{b}}$ \\
T5 & V877 & $4.50^{\mathrm{a}}$ & $4.75^{\mathrm{a}}$ & $4.25^{\mathrm{c}}$ & $4.75^{\mathrm{b}}$ \\
T6 & Winterfield 2512 & $4.88^{\mathrm{a}}$ & $4.88^{\mathrm{a}}$ & $4.38^{\mathrm{c}}$ & $4.50^{\mathrm{b}}$ \\
\hline
\end{tabular}

${ }^{1}=$ intermediate strain.

${ }^{2}=$ intermediate plus strain.

* M eans with different subscripts with the same column differ significantly $(p<0.05)$.

**IBD control group: non vaccinated against IBD.

\section{Histological observation}

Based on lesions distribution and scores (Table4) at 17 and 21 days of age, it was not found significant differences in theBF of birds from T1, T2 and T3 and T4groups. After 28 days of age, birds from T4, T5 and T6 groups had scores equal or higher than 3.

\section{Image processing analysis}

According to the results shown in Table 5, there was more lymphocyte depletion in T4, T5 and T6 groups in comparison to theother ones $(p<0.05)$ due to the more evident pathogenic ability in these kindkinds of vaccines ("hot" strains) over the BF. There was a little recovery and elevation in the percentage of B-lymphocytes in the BF at 35 days of age in these groups.

Table 4 - Quantitative histological analysis of Bursa of Fabricius expressed in lesion scores of the experimental groups at different ages. Quantitativelesion scores from histological analysis of the Bursa of Fabricius expressed of the experimental groups at different ages.

\begin{tabular}{|c|c|c|c|c|c|}
\hline \multirow{3}{*}{ Groups } & \multirow{3}{*}{ Vaccines } & \multicolumn{4}{|c|}{$\begin{array}{c}\text { Mean of histological } \\
\text { analysis of } \\
\text { Bursa of Fabricius }\end{array}$} \\
\hline & & \multicolumn{4}{|c|}{ Age (days) } \\
\hline & & 17 & 21 & 28 & 35 \\
\hline $\mathrm{T} 1^{* *}$ & - & $0^{a}$ & $0^{a}$ & $0^{a}$ & $0^{a}$ \\
\hline $\mathrm{T} 2$ & Lukert $^{1}$ & $0^{a}$ & $0.25^{\mathrm{a}}$ & $0^{a}$ & $0^{a}$ \\
\hline T3 & Lukert $^{2}$ & $0^{a}$ & $0.25^{\mathrm{a}}$ & $0.25^{a}$ & $0.25^{a}$ \\
\hline T4 & $228 \mathrm{E}$ & $0.25^{a}$ & $0.5^{\mathrm{a}}$ & $2.5^{b}$ & $3^{b}$ \\
\hline T5 & V877 & $0.5^{b}$ & $1.5^{b}$ & $2.5^{b}$ & $3.25^{b}$ \\
\hline T6 & Winterfield 2512 & $0.5^{b}$ & $1.5^{b}$ & $3^{b}$ & $3.25^{b}$ \\
\hline
\end{tabular}

${ }^{1}=$ intermediate strain

${ }^{2}=$ intermediate plus strain

*Means with different subscripts with the same column differ significantly $(p<0.05)$

**IBD control group: non vaccinated against IBD

Table 5 - M ean of lymphocyte percentage in the bursa.

\begin{tabular}{|c|c|c|c|c|c|}
\hline \multirow{2}{*}{\multicolumn{2}{|c|}{ Groups Vaccines }} & \multicolumn{4}{|c|}{$\begin{array}{l}\text { Mean of lymphocyte } \\
\text { percentage in the bursa }\end{array}$} \\
\hline & & \multicolumn{4}{|c|}{ Age (days) } \\
\hline & & 17 & 21 & 28 & 35 \\
\hline $\mathrm{T} 1^{* *}$ & - & $43.62^{a^{*}}$ & $42.50^{a}$ & $40.92^{a}$ & $44.06^{a}$ \\
\hline T2 & Lukert $^{1}$ & $41.99^{\mathrm{ab}}$ & $38.43^{a b}$ & $38.34^{a}$ & $43.44^{a}$ \\
\hline T3 & Lukert $^{2}$ & $39.34^{\mathrm{ab}}$ & $36.49^{\mathrm{ab}}$ & $34.44^{a}$ & $37.19^{a}$ \\
\hline T4 & $228 \mathrm{E}$ & $36.64^{c}$ & $36.01^{\mathrm{ab}}$ & $25.71^{\mathrm{b}}$ & $28.05^{b}$ \\
\hline T5 & V877 & $32.13^{c}$ & $30.30^{c}$ & $23.45^{b}$ & $26.58^{b}$ \\
\hline T6 & Winterfield 2512 & $33.00^{c}$ & $28.06^{c}$ & $16.29^{b}$ & $28.05^{b}$ \\
\hline \multicolumn{6}{|c|}{$1=$ intermediate strain } \\
\hline \multicolumn{6}{|c|}{${ }^{2}=$ intermediate plus strain } \\
\hline \multicolumn{6}{|c|}{ *Means with different subscripts with the same columr } \\
\hline
\end{tabular}

\section{Serological analysis}

Geometricmean of antibody titersin T1,T2 and T3 groups presented declination along the time. Birds 
from T4, T5 and T6 groups had higher levels of antibody titers at 35 days of age, indicating the competence of producing neutralizing antibodies against IBD after vaccination (Table 6).

Table 6 - Geometric means of titers of neutralizing antibodies against IBDV in broilers at one, 14, 21, 28 and 35 days of age by ELISA test (log 10), in the different treatments.

\begin{tabular}{|c|c|c|c|c|c|}
\hline \multirow[t]{3}{*}{ Groups } & \multirow[t]{3}{*}{ Vaccines } & \multicolumn{4}{|c|}{$\begin{array}{l}\text { Geometric means of IBDV } \\
\text { titers by ELISA test (log 10) }\end{array}$} \\
\hline & & \multicolumn{4}{|c|}{ Age (days) } \\
\hline & & 17 & 21 & 28 & 35 \\
\hline $\mathrm{T} 1 * *$ & - & $3.73^{a^{*}}$ & $3.11^{a}$ & $2.67 \underline{a}$ & $2.66^{\mathrm{a}}$ \\
\hline T2 & Lukert $^{1}$ & $3.73^{a}$ & $3.03^{a}$ & $2.75^{a}$ & $2.82^{\mathrm{a}}$ \\
\hline T3 & Lukert $^{2}$ & $3.73^{a}$ & $3.18^{a}$ & $2.81^{\mathrm{a}}$ & $2.69^{a}$ \\
\hline T4 & $228 \mathrm{E}$ & $3.73^{a}$ & $3.19^{a}$ & $2.75^{a}$ & $3.05^{\mathrm{ab}}$ \\
\hline T5 & V877 & $3.73^{a}$ & $3.30^{a}$ & $2.76^{\mathrm{a}}$ & $3.38^{b}$ \\
\hline T6 & Winterfield 2512 & $3.73^{a}$ & $3.05^{a}$ & $2.94^{\mathrm{a}}$ & $3.32^{b}$ \\
\hline \multicolumn{6}{|c|}{$\begin{array}{l}\text { *M eans with different subscripts with the same column } \\
\text { differ significantly }(p<0.05) \\
\text { ** IBD control group: non vaccinated against IBD }\end{array}$} \\
\hline
\end{tabular}

Experiments 2:During the challenge period, 15/ 16 birds from T1 group presented signs and macroscopic lesions of IBD, such as ruffled feathers, whitish diarrhea, depression and severeprostration.
The BF presented gelatinous yellowish transudate covering the serosal surface. Birds from T2 (10/ 16) and T3 (4/ 16) groups presented clinical signs of the disease and macroscopic lesion in the bursa and kidney, such as T1 group. N one of the birds from T4, T5 and T6 groups showed any alteration or IBD clinical signs.

Experiment 3: Data in Table 7 revealed that none of the five IBD vaccines was immunosuppressive. Birds receiving any of thefivelBD vaccines wereable to produce as high NDV antibody titer and were as resistant to ND clinical challenge infection as birds from T1 group that were vaccinated against ND but not against IBD. Birds from T7 group that were not vaccinated against ND were totally susceptible to NDV challenge (16/ 16).

\section{DISCUSSION}

Body weight ratio is one of the most important parameters to evaluate the immunosuppression caused by IBD virus and by IBD vaccines (BoLIs etal., 2003). The first experiment demonstrated that only chicks from T4, T5 and T6 groups presented considerablereduction in theBFRW (Table2) and in thediameter of BF parameters. This can beexplained by the lower degree of attenuation of this kind of vaccine, who was capable to destroy B-lymphocytes present on theBF, reducing their size. It is rel evant to show that there were not an important reduction of BFRW and diameter of BF in T2 and T3groups. More severe histological lesions and lower percentage of lymphocytes in theBF wereobserved in broilersfrom

Table 7 - N ewcastle Disease (ND) serology and challenge.

\begin{tabular}{|c|c|c|c|c|c|c|}
\hline \multirow[t]{3}{*}{ Groups } & \multirow[t]{3}{*}{ IBD vaccines ( 14 days) } & \multirow[t]{3}{*}{ ND vaccine (21 days) } & \multicolumn{3}{|c|}{ Means of ND titers by $\mathrm{HI}$ test $(\log 2)$} & \multirow{3}{*}{$\begin{array}{c}\text { NDV challenge } \\
\text { 10dpi }\end{array}$} \\
\hline & & & \multicolumn{3}{|c|}{ Age (days) } & \\
\hline & & & 21 & 28 & 35 & \\
\hline $\mathrm{T} 1^{* *}$ & - & LaSota & $5.13^{a^{*}}$ & $4.87^{a}$ & $7.47^{\mathrm{a}}$ & $0 / 16$ \\
\hline T2 & Lukert $^{1}$ & LaSota & $4.50^{\mathrm{a}}$ & $5.97^{a}$ & $8.06^{a}$ & $0 / 16$ \\
\hline T3 & Lukert $^{2}$ & LaSota & $4.53^{a}$ & $6.08^{a}$ & $7.10^{\mathrm{a}}$ & $0 / 16$ \\
\hline T4 & $228 \mathrm{E}$ & LaSota & $4.20^{\mathrm{a}}$ & $5.74^{a}$ & $7.99^{a}$ & 0/ 16 \\
\hline T5 & V877 & LaSota & $4.68^{a}$ & $5.34^{a}$ & $7.58^{\mathrm{a}}$ & $0 / 16$ \\
\hline T6 & Winterfield 2512 & LaSota & $4.74^{a}$ & $5.82^{a}$ & $7.59^{a}$ & 0/ 16 \\
\hline $\mathrm{T} 7^{* 2 * k}$ & - & - & $5.12^{\mathrm{a}}$ & $4.46^{a}$ & $3.86^{b}$ & $16 / 16$ \\
\hline
\end{tabular}

\footnotetext{
dpi=days post infection

1 =intermediate strain

${ }^{2}=$ intermediate plus strain

${ }^{*}$ Means with different subscripts with the same column differ significantly $(p<0.05)$

**IBD control group: non vaccinated against IBD

***ND control group: non vaccinated neither against IBD nor ND
} 
T4; T5 and T6groups at 28 and 35 days of age (Tables 4 and 5). This can be explained by the attenuation degree of thelBD vaccinestrainsused in thistrial. Less attenuated strains have the ability to overcome high levels of maternally derived antibodies (MDA), conferring active immunity to the vaccinated chicks (VAN Den BeRG, 2000). A snearly all of thechickenswill have someresidual maternal antibody at one day old of age, amoreinvasive, yet not nonimmunodepressive vaccine would be needed to overcome maternal antibody (GIAMBrone; Clay, 1986). The passive immunity, although protective, interferes with the vaccination. There is a strong competition between field and vaccines strains to break through MDA, and theoptimal timing has becomethe crucial problem in the establishment of the vaccination schedule. Attenuated live vaccines achieve lifelong and broad protection, but possess a residual pathogenicity $\left(V_{\mathrm{AN}}\right.$ DEN BERG, 2000). This residual pathogenicity is ableto inducemore damagein the $\mathrm{BF}$, causing destruction of B-lymphocytes in this organ. "Hot" strain vaccines were able to stimulate the active immunity of chicks vaccinated at 14 days of age, inducing higher levels of neutralizing antibodies observed at 35 days of age in these groups.

Only birds from groups T4, T5 and T6groups were completely protected against vvIBDV challenge. Birds from T1 (15/ 16), T2 (10/16) and T3 (4/ 16) groups succumbed to vvlBD infection, demonstratingthatbirds from these groups were not enough immunized, what was al ready expected for T1 group, whosechicks were notvaccinated againstIBDV. whatwasal ready expected forTlgroup, whosechickswerenotvaccinated against IBDV As intermediate vaccine is more attenuated than intermediateplus vaccine, therewas moreincidence of thediseaseon T2group becausethisstrain of vaccineis notcapabletoovercomehighlevelsof MDA, sothatmost part of the vaccine was probably neutralized by the MDA. So, birds from T2 and T3 groups were only partially protected against the IBD challenge virus. Broilersvaccinated with "hot"strainIBD vaccines(groups T4,T5and T6) werecompleted protected againstvvIBDV challengebecausethey produced neutralizingantibodies titers capable to recognize and neutralize IBD virus. "Hot" strain vaccines areableto break into high levels of MDA and to stimulate the chicks active immunity, withoutbeing neutralized and afterwards destroyed by IBDV antibodies passively acquired. The antibodies were able to neutralize the vVIBDV antigenic epitopes. Thismechanismreduced theinvasion of thesusceptible cells by the virus, protecting the bird against IBDV infection. Theintensity of microscopical terationsin the bursamay bequantified toevaluatethelevel of immunity protection (A BDEL-A LIM; SAIF, 2000; MAAS et al., 2001) or immune modulation of the infection (PoONIA; CHARAN, 2000).
A nother explanation for the $100 \%$ protection of birds from T4, T5 and T6 groups may lay in the homology of the IBD "hot" strain vaccines and the vvIBDV used in this trial. Of the two serotypes, only serotype1strainsarepathogenicfor poultry (JACKWOOD et al., 1984; IsMAIL et al., 1988) and aretherefore used in vaccines. A considerableantigenic diversity exists within serotypelIBDV strains. I ncross-neutralization tests, at least six subtypes can be distinguished with serotype 1 (ACKWOOD; SAIF, 1987). Such subtypes differencescould berelevantfor theprotectionagainst vVIBDV used in thistrial. Theinfluence of the vvIBDV challengestrain on the correlation between serology and protection is either caused by a difference in homology between the individual challenge strains and thevaccinestrains, or by thedifferencein virulence of the challenged strains (MAAs et al., 2001).

Birds from T1 to T6 groups presented high levels of protectiveneutralizing antibody, except T7 group that was not vaccinated against ND. At chal lenged, only group T7 succumbed to the inoculation of the viscerotropicN D virus, demonstratingthat, "hot" strains IBDvaccinesdidnotpresentimmunosuppressiveability in vaccinated broilers.

Although thethree "hot" strain IBD vaccines tested inthisstudy (228E,V877and Winterfield2512) produced slightly atrophic bursa with moderate microscopic lesions, they conferred $100 \%$ protectionagainstvvIBDV challengeand werenotimmunosuppressive.Thisstudy provides data about the use of hot strain IBDV vaccine to control vVIBDV infection in broilers.

REFERENCES

Abdel-Alim, G.A.; Sif, Y.M. Immunogenicity and antigenicity of very virulentstrains of InfectiousBursal Disease Viruses. A vian D iseases, v.45, p.92-101, 2000.

BAXENDALE, W.; L UTTICKEN, D. Theresults of field trials with in inactivated Gumboro vaccine. Developments in Biological Standardization, v.52, p.211-219, 1981.

Bolis,D.A.;Paganini, F.J.;SImon,V.A.;Zuanaze,M.F;Scanavin I Neto,H.;C orrea, A.R.A.;I to, N .M.K.Gumborodisease: evaluation of serological and anatomopathological responses in vaccinated broiler chickens challenged with very virulent virus strain. Revista Brasileira de Ciência A vícola, v.5, n.2, p.137-146, 2003.

Cosgrove, A.S. An apparently new disease of chickens: avian nefrosis. A vian D iseases, v. 6, p. 385-389, 1962.

Di Fabio, J., Rossinı, L.I.; EterradossI , N .; ToQuin, D.; Gardin, Y. European-like pathogenicinfectiousbursal disease virus in Brazil. V eterinary Record, p.203-204, 1999.

Eterradossi, N.; Pcault, J.P.; Drouin, P.; Guittet, M.; L'Hospitalier, R. ; Bennejean, G. Pathogenicity and preliminary antigenic characterization of six infectious bursal disease virus strains isolated in France in acute outbreaks. Z entralblatt fur veterinarmedizin Reihe B, v.39, p.683-691, 1992. 
Eterradossi ,N.;Rivallan ,G.;Toquin, D.;Guittet, M.Limited antigenic variations among recent IBDV isolates from France. A rchives of V irology, v.142, p.2079-2087, 1997.

Giambrone, J.J.; Clay, R.P. Evaluation of the immunogenicity, stability, pathogenicity and immunodepressive potential of four commercial liveinfectious bursal diseasevaccines. Poultry Science, v.65, p.1287-1290, 1986.

Ikuta, N.; El-Attrache, J.; Villegas, P.; Garcia, E.M.; Lunge, V.R.; Fonseca, A.S.; Oiveira, C.; Marques, E.K. Molecular characterization of Brazilian infectious bursal diseaseviruses. A vian D iseases, v.45, n.2, p.297306, 2001.

ISMAIL, N.M.; SAIF, Y.M.; Moorhead, P.D. Lack of pathogenicity of five serotypes 2 IBDV in chickens. A vian D iseases, v.32, p.757-759, 1988.

Iто, N.M.K.DoençadeGumboro: umproblemaaindasem definição. In: CONGRESSO BRASILEIRO DE AVICULTURA - CBA, 70., 1981, Recife. A nais. Recife: 1981. p.260-264.

Іто, N.M.K. Infectious bursal disease: a case report. Brazilian Journal of Veterinary Research and Animal Science, v.27, n.1, p.99-110, 1990.

Іто, N.M.K. O uso de vacinas fortes de Gumboro: benefícios, reflexos e perspectivas futuras. In: SIMPÓSIO FACTA DE POSTURA COMERCIAL, 2002, Campinas. A nais. Campinas: 2002. p.45-59.

JaCkWOOD, D.H.,SAIF,Y.M.,M OORHEAD,P.D.;BISHOP, G.Failure of two serotypell infectious bursal diseaseviruses to affect the humoral immune response of turkeys. A vian D iseases, v.28, p.100-116, 1984.

JACKWOOD,D.H.;SAIF, Y.M. A ntigenicdiversity of infectious bursal diseaseviruses. A vian D iseases, v.31, p.766-770, 1987.

Lobardo, E.; M araver, A.; Casten, J.R.; Rivera, J.; FernandezArias, A.; Serrano, A.; Carrascosa, J.L.; Rodriguez, J.F. VP1, the putative RNA-dependent RNA polymerase of infectious bursal disease virus, forms complexes with the capsid protein VP3, leading encapsidation into virus-like particles. Journal of V irology, v.73, n.8, p.6973-6983, 1999.

LUKERT,P.D.; SAIF, Y.M.I Infectious bursal disease. In:CALNEK, B.W.; Arnes, H.J.; Eard, C.W.; Mcdougald, L.R.; Salf, Y.M. (Eds.). D isease of poultry. 9ed. Ames: Iowa State University Press, 1997. p.721-738.
MaAs, R.A.; Venema, S.; Orı, H.L.; Pol, J.M.A.; Gaassen, I.J.T.M.;TER HuURNe, A.A.H.M. Efficacy of inactivated infectious bursal disease (IBD) vaccines: comparison of serology with protection of progeny against IBD virus strains of varying virulence. A vian Pathology, v.30, p.345-354, 2001.

Poonia, B.; Charan, S. T-cell suppression by cyclosporinA enhances infectious bursal disease virus infection in experimentally infected chickens. A vian Pathology, v.30, p.311-319, 2000.

SAUKAS, T.N. Caracterização de amostra do vírus da doença bursal (doença de Gumboro) isolada no Brasil. 1978. 88p. Dissertação (M estrado) - Universidade Rural do Rio de Janeiro, Rio de Janeiro, 1978.

Schröder, A.; Van Loon, A.A.W.M.; Goovaerts, D.; Mundt, E. Chimerasin noncoding regionsbetween serotypes I and II of segmentA of infectious bursal diseasevirus are viable and show pathogenic phenotype in chickens. Journal of General V irology, v.81, n.2, p.533540, 2000.

Sellers, H.S.; Vlleggas, P.N.; Sal, B.S.; jackwood, D.J. Antigenic and molecular characterization of three infectious bursal disease virus fields isolates. A vian D iseases, v.43, p.198-206, 1999.

Skeeles, J.K.; Lukert, P.D.; Fletcher, O.J.; Leonard, J.D. Immunization studies with a cell-culture-adapted infectious bursal disease virus. A vian D iseases, v.23, p.107-117, 1979.

SKINNER, M.A. Very virulent strains of IBDV. In: WORLD POULTRY CON GRESS, 21., 2000. Montreal, Canada. A nais. Montreal: 2000. CD-ROM.

U.S. Code OfFederal Regulations. A nimal andanimal products. Washington: Office of theFederal Register N ational Archives And Records A dministration, 1993. 818p.

Van den Berg, T.P.; Meulemans, G. Acute infectious bursal disease in poultry: protection afforded by maternally derived antibodies and interference with live vaccination. A vian Pathology, v.20, p.409421, 1991.

Van den Berg, T.P. Acute Infectious Bursal Disease in poultry: a review. A vian Pathology, v.29, n.1, p.175-194, 2000.

Received on 21/ 8/ 06 Accepted on 17/ 9/ 07 